Journal of Southeast Asian

\title{
Book Review: Cambodian American Experiences: Histories, Communities, Cultures and Identities, by Jonathan H. X. Lee
}

Khatharya Um

University of California, Berkeley, umk@berkeley.edu

\section{Recommended Citation}

Um, Khatharya (2012) "Book Review: Cambodian American Experiences: Histories, Communities, Cultures and Identities, by Jonathan H. X. Lee," Journal of Southeast Asian American Education and Advancement. Vol. 7 : Iss. 1, Article 5.

DOI: 10.7771/2153-8999.1047

Available at: https://docs.lib.purdue.edu/jsaaea/vol7/iss1/5

This document has been made available through Purdue e-Pubs, a service of the Purdue University Libraries. Please contact epubs@purdue.edu for additional information.

This is an Open Access journal. This means that it uses a funding model that does not charge readers or their institutions for access. Readers may freely read, download, copy, distribute, print, search, or link to the full texts of articles. This journal is covered under the CC BY-NC-ND license. 


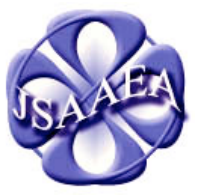

Volume 7 (2012)
Journal of Southeast Asian American

Education \& Advancement

WWW.JSAAEA.org
A peer-reviewed

scholarly journal published by the National Association for the Education \& Advancement of Cambodian, Laotian, and Vietnamese Americans (NAFEA)

\title{
Lee, Jonathan H. X. (Ed.). (2010). Cambodian American Experiences: Histories, Communities, Cultures and Identities. Dubuque, IA: Kendall Hunt Publishing. 484 pp. \$70.90 (Paperback). ISBN: 978-0-7575-8417-6
}

\author{
Reviewed by \\ Khatharya Um \\ University of California, Berkeley
}

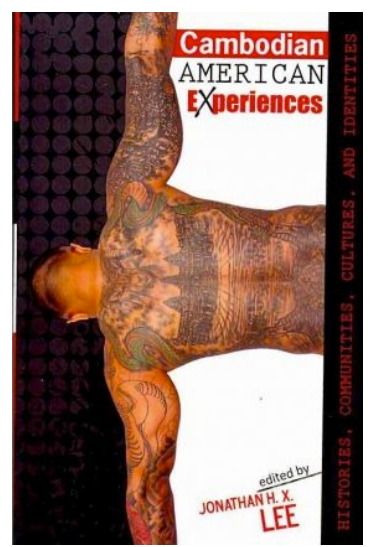

Jonathan Lee's edited volume, Cambodian American Experiences, traces the historical developments that engendered Cambodian migration to, and community formation in the US, and provides a wide coverage of key issues relating to their incorporation experiences, ranging from educational challenges to gender and sexual politics. The thirty-four chapters of the volume, excluding the introduction and epilogue, are clustered into twelve sections and organized, to a large extent, chronologically and thematically. Section I opens with an abbreviated history of Cambodia, dating from the pre-Angkorian period through the rise and fall of the Khmer Empire, the French protectorate, the postindependence Sihanoukist era, the expansion of the Vietnam War into Cambodia, the Khmer Rouge period, and ending with the collapse of Democratic Kampuchea. Section II on the "push factors" consists of articles on the saturated bombing of Cambodia between 1971 and 1973, Pol Pot's biography, the Tuol Sleng extermination center (also known as S-21) and an abbreviated discussion of the nature of the Khmer Rouge revolution. Section III, entitled the "pull factors," begins with the dislocations of the turbulent 1970s, and includes chapters on the refugee exodus from Cambodia and proliferation of refugee camps along the Cambodian-Thai border, and on the evolution of the United States refugee admission policies that informed the community formation and demographics of the Cambodian population that was resettled in the US between 1975-1987. Susan Needham and Karen Quintiliani's article on Cambodian refugees' post-resettlement internal migration, principally to southern California, complements Sucheng Chan's chapter on the emergence of Long Beach as the "Cambodian Capital in America."

The themes of migration and community formation are picked up again in Carol Mortland's article in Section IV, and other chapters on adjustment issues such as mental health and gangs. Education, one of the key challenges facing the Cambodian American community, is covered in three chapters of Section $V$. Traditions and innovations in Cambodian American

\section{@)}

SOBRERIGHISRESERVED Readers are free to copy, display, and distribute this article, as long as the work is attributed to the author(s) and the Journal of Southeast Asian American Education \& Advancement, it is distributed for noncommercial purposes only, and no alteration or transformation is made in the work. More details of this Creative Commons license are available at http://creativecommons.org/licenses/by-nc-nd/3.0/. All other uses must be approved by the author(s) or JSAAEA. 
cultural production are addressed in Section VI in the writings of two generationally different scholars, Drs. Sam-Ang Sam and Cathy J. Schlund-Vials. Approached, moreover, from two different disciplinary perspectives, namely ethnomusicology and cultural studies, they examine different genres of music and performances, spanning the traditional repertoires of pin peat and lkhaon kbach to rap and Hip Hop. Section VII covers the subject of literary production and writings by and of Cambodian Americans. Teri Yamada's chapter on autobiographies provides a pioneering documentation of the production of knowledge by Cambodian diasporas that countervails the frequently held notions of Cambodians as bereft of agency by trauma. Section VIII returns to the incorporation issues, focusing on different topics related to economic integration from a cultural analysis of economic behavior, to the rise of Cambodian American presence in the doughnut microenterprise, to welfare dependency and the racial and gendered politics of welfare reform. Lynn Fujiwara and Michael Truong's articles situate the 1996 welfare reforms within the larger context of racial politics and anti-immigrant debates within the United States. Truong's study looks at the reforms as disciplinary implements of liberal governance, while Fujiwara not only highlights their gendered implications but, importantly, the agency of immigrant and refugee communities as demonstrated in their advocacy campaigns.

The topics of identity formation, gender, sexuality and religion are addressed in the ensuing three sections. The articles by Kuong Chhang Ly and Jonathan Lee in Section IX both address the issues of ethnic pluralism and cultural hybridity in the Cambodian American community and how they are further complicated by the displacement and reincorporation experiences. Christine Su's chapter discusses the different and evolving narratives of Khmerness, a theme that she picks up in a later chapter about Cambodian American women and that threads through Section $\mathrm{X}$ in the analyses of the precarious tension between culturally inscribed practices, gendered expectations, and personal choice as they involve marriage partners and sexual identities. Cambodian American search for identity, meaning and healing after the genocidal encounters reverberates in the discussion of religiosity and "culture works" in Section XI. Sylvia Cowan's article in Section XII on the deportation of non-citizen permanent residents brings the issue of refugee migration to a full and ironic circle.

Of all the chapters, those dealing with education, youth and identity politics are perhaps the most developed, involving original research and more substantive engagement with the topic. Chhuon and Wright's works shed interesting light on the relationship between culture, language, identity and educational advancement despite the slipperiness of the cultural arguments that creep into some of the analyses in the section. The scholarship on youth and identity, though of varying stage of development, provides interesting insights both through the engagement of new topics namely generational, gender and sexual politics but also through the excavation of new archival sources, as Susan Needham did with Cambodian American college student journals. This, in many ways, is a reflection of the greater scholarly interest and emergent scholarship in these areas.

The broad coverage of the issues pertinent to the Cambodian American experience is both the strength and the weakness of the volume. Though illuminating of the multifaceted nature of the issues, the shortcoming is in the compromise made to the depth of their treatment. Though the chapters are numerous and the issues covered expansive, author contributions are of uneven quality and substance. Some chapters, such as the ones dealing with mental health and gangs, address complex and delicate subjects but do not provide the necessary methodological contexts to inform readers of how data was secured and analyzed. Some would have benefitted also from more meticulous editing. Moreover, with the exception of a few, most of the chapters 
are exceedingly short reprints of articles and excerpts from published books, without the depth necessary to do justice to the subject matters. Fifty percent of the volume consists of chapters that are less than ten pages long, including bibliographies; only three articles are over twenty pages long. Cambodia's history from the pre-Angkorian period to the collapse of Democratic Kampuchea, involving at least five major regime changes ranging from absolute monarchy to radical communism, was condensed to twelve pages of text, of which a little over four pages are dedicated to Cambodia's entire post-colonial history. Compounding the problem, the organization of the volume appears disjointed in places, further adding to the feel of a mere "listing" of issues. The volume thus would have benefitted from greater contextualization or framing to give readers a better idea of the rationale behind the selection and organization of the topics and chapters.

Though useful as a handbook for a general readership interested in a quick, introductory survey of issues, the rather superficial treatment of some extremely complex topics makes the volume less appropriate as an academic text for adoption at the university level. Rather than attempting such a broad but relatively shallow treatment of these important and involved issues, the volume would have been strengthened by selection of a few topics, and fewer but more substantive chapters. It would also be aided by less reliance on reprinted works, inclusion of more recent studies, and a more explicitly articulated organizing logic of how the different facets of the displacement and re-emplacement experiences fit together. Attempting to holistically and fully capture the migration journey and experiences is, without a doubt, a daunting task.

\begin{abstract}
About the Author
Professor Khatharya Um is Associate Professor of Asian American and Asian Diaspora Studies, and Chair of Peace and Conflict Studies at the University of California Berkeley. She received her Ph.D in Political Science from the University of California, Berkeley and was a Chancellor's Distinguished Postdoctoral Fellow. Her research and teaching interests focus simultaneously on Southeast Asia and Southeast Asian American communities and include politics and societies of Southeast Asia, refugee, diaspora and transnational studies, postcolonial studies, and genocide studies. In addition to her academic work, Professor Um is also actively involved in community advocacy, principally on issues of social and educational equity for linguistic minorities and students of color and their families. She has served on numerous national and community boards and is widely recognized for her community leadership and service. She is a 2011-2012 Chancellor's Public Scholar.
\end{abstract}




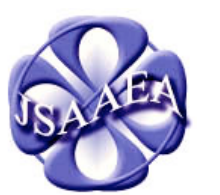

Volume 7 (2012)

\section{Journal of Southeast Asian American Education \& Advancement}

\author{
WWW.JSAAEA.org
}

\section{Editor}

Dr. Wayne E. Wright

University of Texas, San Antonio

\author{
Associate Editors \\ Dr. Chhany Sak-Humphry \\ University of Hawaii at Manoa
}

Dr. Phitsamay Sychitkokhong Uy

University of Massachusetts, Lowell

\section{Book Review Editor}

Dr. Vichet Chhuon

University of Minnesota

\section{Creative Works Editor \\ Bryan Thao Worra \\ Lao Assistance Center}

Special Advisor

Gregory Green

Curator, Echols Collection on Southeast Asia, Cornell University Library

\section{Journal Manager}

Sovicheth Boun

University of Texas, San Antonio
A peer-reviewed scholarly journal published by the

National Association

for the Education \&

Advancement of

Cambodian, Laotian,

and Vietnamese

Americans (NAFEA)

Comments and questions for the editorial staff may be directed to jsaaea@1ists.sis.utsa.edu

\section{Editorial Review Board}

\author{
Dr. Steve Arounsack \\ California State University, Stanislaus \\ Dr. Phala Chea \\ Lowell Public Schools \\ Dr. Loan Dao \\ University of Massachusetts, Boston \\ Dr. Changming Duan \\ University of Missouri, Kansas City \\ Dr. Jeremy Hein \\ University of Wisconsin - Eau Claire \\ Dr. Samlong Inthaly \\ Minneapolis Public Schools \\ Dr. Kevin K. Kumashiro \\ University of Illinois, Chicago
}

Dr. Carl L. Bankston III

Tulane University

Dr. George Chigas

University of Massachusetts, Lowell

Dr. Hien Duc Do

San Jose State University

Dr. Sophal Ear

U.S. Naval Postgraduate School

Dr. Nancy H. Hornberger

University of Pennsylvania

Dr. Peter Nien-Chu Kiang

University of Massachusetts, Boston

Dr. Ha Lam

Arizona State University 


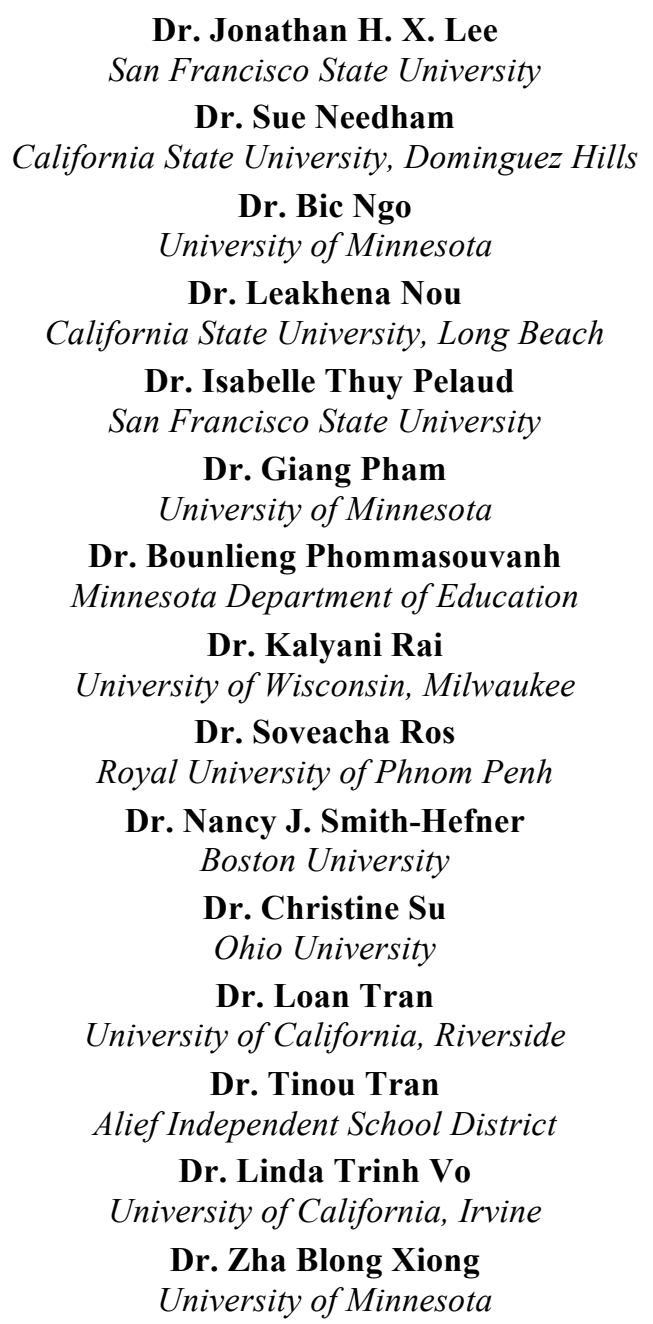

\section{Doctoral Student Editorial Review Board}

\author{
Keo Chea-Young \\ University of Pennsylvania \\ Ketmani Kouanchao \\ California State University, Fullerton \\ Ravy Lao \\ University of California, Santa Barbara \\ Thien-Huong Ninh \\ University of Southern California \\ Vanna Som \\ Harvard University \\ Krissyvan Truong \\ Claremount Graduate University \\ Yang Sao Xiong \\ University of California, Los Angeles
}

\author{
Dr. Stacey Lee \\ University of Wisconsin, Madison \\ KimOanh Nguyen-Lam \\ U.S. Department of Education \\ Dr. Max Niedzwiecki \\ Daylight Consulting Group \\ Dr. Clara Park \\ California State University, Northridge \\ Dr. Mark Pfeifer \\ SUNY Institute of Technology \\ Dr. Loan T. Phan \\ University of New Hampshire \\ Dr. Karen Quintiliani \\ California State University, Long Beach \\ Dr. Angela Reyes \\ Hunter College, The City University of New York \\ Dr. Fay Shin \\ California State University, Long Beach \\ Dr. Cathy J. Schlund-Vials \\ University of Connecticut, Storrs \\ Dr. Yer J. Thao \\ Portland State University \\ Dr. Myluong Tran \\ San Diego State University \\ Dr. Khatharya Um \\ University of California, Berkeley \\ Dr. Terrence G. Wiley \\ Center for Applied Linguistics \\ Dr. Kou Yang \\ California State University, Stanislaus
}

\author{
Annie BichLoan Duong \\ San Joaquin County Office of Education \\ Peter Tan Keo \\ Columbia University \\ Monirith Ly \\ Texas State University-San Marcos \\ Malaphone Phommasa \\ University of California, Santa Barbara \\ Alisia Tran \\ University of Minnesota \\ Silvy Un \\ University of Minnesota \\ Yeng Yang \\ University of Texas, San Antonio
}

